\title{
HUBUNGAN KEHARMONISAN KELUARGA DENGAN KONSEP DIRI SISWA
}

Correlation The Family Harmony to the Student Self-Concept

\author{
Nurhasnah, M.Pd*) \\ asnahnasti93@gmail.com
}

*) Dosen Institut Agama Islam Sumater Barat

\section{Abstract}

This research is motivated by various problems experienced by students to form and develop self-concepts. Harmony is one of the factors that are considered to influence the development of students self-concepts. This study aims to illustrate: (1) family harmony, (2) self-concept, (3) family harmony relationship with self concept. This study uses quantitative method of descriptive type correlation. The research population is 332 students of SMAN 1 Rao Pasaman. A sample of 182 students, selected with Proportional Stratified Random Sampling. The instrument used is a likert scale model. The results showed that: (1) the harmony of the student's family was in the harmonious category with a percentage of $77.55 \%$ of the ideal, (2) the student's self-concept was in the positive category with a percentage of $68.88 \%$ of the ideal, (3) there was a positive and significant relationship between family harmony and self-concept, the contribution of family harmony to the self-concepts by $19 \%$. This means that family harmony variables can be used as predictors to predict self-concepts.

Key words: Family harmony, Self-concept.

\begin{abstract}
Abstrak
Penelitian ini dilatarbelakangi oleh berbagai permasalahan yang dialami siswa untuk membentuk dan mengembangkan konsep diri. Keharmonisan keluarg menjadi salah satu faktor yang dianggap mempengaruhi perkembangan konsep mahasiswa. Penelitian ini bertujuan untuk menggambarkan: (1) keharmonisan keluarga, (2) konsep diri, (3) hubungan keharmonisan keluarga dengan konsep diri. Penelitian ini menggunakan metode kuantitatif korelasi tipe deskriptif. Populasi penelitian adalah 332 siswa SMAN 1 Rao Pasaman. Sampel 182 siswa, dipilih dengan Proporsional Stratified Random Sampling. Instrumen yang digunakan adalah model likert scale. Hasil penelitian menunjukkan bahwa: (1) keharmonisan keluarga siswa berada dalam kategori harmonis dengan persentase $77,55 \%$ dari ideal, (2) konsep diri siswa berada dalam kategori positif dengan persentase 68,88\% dari ideal, (3) terdapat hubungan yang positif dan signifikan antara keharmonisan keluarga dan konsep diri, kontribusi keharmonisan keluarga terhadap konsep diri sebesar 19\%. Ini berarti bahwa variabel keharmonisan keluarga dapat digunakan sebagai prediktor untuk memprediksi konsep diri.

Kata kunci: Keharmonisan keluarga, Konsep diri.
\end{abstract}

\section{PENDAHULUAN}

Siswa sebagai individu yang berada dalam proses perkembangan, senantiasa mengalami perubahan tingkah laku dan kepribadian sebagai hasil dari proses belajar. Siswa dapat mengembangkan kepribadian dan keterampilan dengan segala karakterisitik yang dimiliki. Siswa yang berada pada tingkat Sekolah Menengah Atas (SMA) umumnya memiliki rentang usia 15-18 tahun dan merupakan masa peralihan dari masa kanak-kanak menuju masa dewasa atau yang lebih sering 
dikenal dengan istilah masa remaja. Artinya siswa SMA berada pada usia perkembangan remaja.

Papalia \& Feldman (2014) menjelaskan bahwa pada masa remaja selain mengalami pertumbuhan fisik, remaja juga menunjukkan perkembangan kognitif, emosional, otonomi, harga diri, dan intimasi. Hal tersebut merupakan beberapa aspek psikologis yang dapat menunjang perkembangan kepribadian remaja. Remaja yang dalam hal ini adalah siswa SMA memiliki hubungan yang cenderung kuat dengan orangtua, sekolah, dan komunitasnya, cenderung berkembang dengan cara yang positif dan sehat. Akan tetapi, tidak semua siswa mengalami perkembangan perilaku yang positif, siswa akan menghadapi ancaman dan permasalahan berkaitan dengan keadaan fisik atau psikologis, maupun kesejahteraan mental.

Permasalahan yang dialami oleh siswa dapat menghambat perkembangan kepribadian mereka dan butuh penanggulangan. Lingkungan sekolah merupakan salah satu tempat bagi siswa untuk mengembangkan kepribadian terutama konsep diri siswa yang diperoleh melalui pendidikan formal, salah satunya dengan pelayanan Bimbingan dan Konseling (BK). Pelaksanaan pelayanan bimbingan dan konseling dilaksanakan oleh Guru BK/Konselor. Guru BK/Konselor membantu siswa dalam mengembangkan konsep diri siswa ke arah yang lebih positif melalui kegiatan bimbingan klasikal, kelompok, maupun individual. Bimbingan di sekolah memusatkan pelayanan pada siswa sebagai individu yang perlu memanfaatkan pendidikan sekolah bagi perkembangan dirinya dalam setiap aspek kepribadian (Winkel, 2007). Salah satu aspek kepribadian yang paling penting bagi remaja adalah konsep diri.

Konsep diri merupakan pandangan seseorang tentang dirinya.
Familia (2006) menyatakan bahwa konsep diri adalah pandangan dan sikap individu terhadap diri sendiri. Pandangan diri terkait dengan dimensi fisik, karakterisktik individu, dan motivasi diri. Pandangan diri tidak hanya meliputi kekuatan-kekuatan individual, tetapi juga kelemahan bahkan kegagalan dirinya. Konsep diri adalah inti kepribadian individu.

Berdasarkan uraian di atas, salah satu faktor yang mempengaruhi konsep diri adalah hubungan dalam keluarga. Keluarga merupakan bagian terpenting dari kehidupan seorang anak, karena di dalam keluarga anak pertama kali belajar tentang segala hal, baik tentang interaksi, komunikasi, dan norma-norma. Keluarga juga mempunyai peran penting dalam pembentukan konsep diri. Kasih sayang, perhatian, kehangatan, kerjasama, komunikasi, dan keutuhan keluarga sangat dibutuhkan untuk membentuk konsep diri.

Calhoun \& Accocella (dalam Ghufron \& Risnawati, 2010) menyatakan bahwa orangtua merupakan figur untuk berinteraksi yang paling awal dan paling kuat dalam pembentukan kerangka dasar konsep diri. Saat masa kanak-kanak, orang yang memiliki pengaruh besar dalam perkembangan konsep diri individu adalah orang yang paling dekat dengan diri individu yang disebut significant others, yaitu orangtua. Orangtua memberikan rasa aman, kondisi yang nyaman, serta kasih sayang. Hal ini merupakan beberapa aspek dalam proses pembentukan keluarga harmonis.

Darahim (2015) menjelaskan keharmonisan keluarga adalah suasana yang damai, bahagia, sejahtera, saling pengertian, saling menghargai, dan saling kerjasama dalam rangka membina toleransi dalam keluarga. Keluarga pertama menggambarkan dukungan, kehangatan, pujian, dan kasih sayang orangtua kepada anaknya, hasilnya akan berdampak pada pembentukan konsep diri yang positif. Keluarga kedua, 
menggambarkan orangtua yang tidak memberikan dukungan, seperti: acuh tak acuh, tidak menyatakan kasih sayang kepada anaknya, maka hasilnya anak akan mengalami proses pembentukan konsep diri yang negatif. Berdasarkan permasalahan di atas maka peneliti tertarik untuk membahas suatu masalah dengan judul "Hubungan Keharmonisan Keluarga dengan Konsep Diri Siswa SMAN 1 Rao Pasaman".

Tujuan penelitian ini adalah untuk: (1) mendeskripsikan keharmonisan keluarga siswa di SMAN 1 Rao Pasaman, (2) mendeskripsikan konsep diri siswa di SMAN 1 Rao Pasaman, (3) menguji hubungan keharmonisan keluarga dengan konsep diri siswa di SMAN 1 Rao Pasaman,

\section{METODE PENELITIAN}

Penelitian ini menggunakan pendekatan kuantitatif dengan jenis deskriptif korelasional. Populasi penelitian adalah peserta didik kelas XI SMAN 1 Rao Pasaman sebanyak 332 siswa. sampel dalam penelitian ini sebanyak 182 siswa. penarikan sampel menggunakan teknik Proportional Sratified Random Sampling. Instrumen yang digunakan pada penelitian ini berupa skala Likert. Hasil uji reliabilitas konsep diri sebesar 0,930 dan keharmonisan keluarga sebesar 0,914. Untuk mengetahui hubungan variabel bebas dengan variabel terikat dianalisa menggunakan regresi sederhana dan regresi ganda. Analisis data dibantu dengan menggunakan program Statistical Product and service Solution (SPSS) versi 20.0.

Pengambilan sampel mengikut nisbah tahap kesilapan 0.05 dan tahap keyakinan $95 \%$, sehingga jumlah sampel adalah 400 orang yang dikumpulkan menggunakan teknik pensampelan multistage sampling (penarikan sampel banyak tahap).

\section{HASIL PENELITIAN Deskripsi Data}

Data dalam penelitian ini meliputi variabel keharmonisan keluarga $\left(\mathrm{X}_{1}\right)$, status sosial ekonomi $\left(\mathrm{X}_{2}\right)$, dan konsep diri (Y). Berikut dikemukakan deskripsi data hasil penelitian.

\section{Deskripsi Data Keharmonisan Keluarga}

Data mengenai tingkat keharmonisan keluarga siswa dapat dilihat pada Tabel 1.

Tabel 1. Deskripsi Rata-rata (Mean) dan Persentase Keharmonisan Keluarga (X)

\begin{tabular}{|c|c|c|c|c|c|c|c|c|c|}
\hline \multirow[b]{2}{*}{$\begin{array}{l}\mathbf{N} \\
\mathbf{0}\end{array}$} & \multirow[b]{2}{*}{ Indikator } & \multicolumn{8}{|c|}{ SKOR } \\
\hline & & Ideal & $\operatorname{Max}$ & Min & $\Sigma$ & $\begin{array}{c}M e a \\
n\end{array}$ & $\%$ & Sd & Ket \\
\hline 1 & Kasih sayang antar anggota keluarga & 40 & 40 & 22 & 5504 & 32,38 & 80,94 & 3,98 & $\mathrm{H}$ \\
\hline 2 & $\begin{array}{l}\text { Saling pengertian sesama anggota } \\
\text { keluarga }\end{array}$ & 45 & 45 & 22 & 5937 & 34,92 & 77,61 & 4,59 & $\mathrm{H}$ \\
\hline 3 & Komunikasi dalam keuarga & 30 & 30 & 14 & 3816 & 22,45 & 74,82 & 3,42 & $\mathrm{H}$ \\
\hline 4 & $\begin{array}{l}\text { Mempunyai waktu bersama dan } \\
\text { bekerjasama dalam keluarga }\end{array}$ & 25 & 25 & 10 & 3200 & 18,82 & 75,29 & 2,83 & $\mathrm{H}$ \\
\hline & Keseluruhan & 140 & 138 & 77 & $\begin{array}{c}1845 \\
7\end{array}$ & 108,5 & 77,55 & 12,5 & $\mathrm{H}$ \\
\hline
\end{tabular}

Gambar 1. Deskripsi Rata-rata (Mean) dan Persentase Keharmonisan Keluarga 
Berdasarkan Tabel 1 diperoleh informasi bahwa, dari keseluruhan indikator keharmonisan keluarga siswa secara rata-rata berada pada kategori harmonis $(\mathrm{H})$ dengan persentase sebesar $77,55 \%$ dari skor ideal. Keharmonisan keluarga diperoleh dari kasih sayang antar anggota keluarga, sikap saling pengertian, komunikasi, mempunyai waktu bersama dan bekerjasama dalam keluarga. Keharmonisan keluarga siswa dapat digambarkan melalui interaksi yang baik di rumah, di sekolah, maupun di lingkungan masyarakat.

\section{Deskripsi Data Konsep Diri}

Data mengenai tingkat keharmonisan keluarga siswa dapat dilihat pada Tabel 2 .

Tabel 2. Deskripsi Rata-rata (Mean) dan Persentase Konsep Diri (Y)

\begin{tabular}{c|l|c|c|c|c|c|c|c|c}
\hline \multirow{2}{*}{ No } & \multicolumn{10}{c}{ SKOR } \\
\cline { 2 - 11 } & Indikator & Ideal & Max & Min & $\boldsymbol{\Sigma}$ & Mean & $\%$ & Sd & Ket \\
\hline 1 & Fisik & 35 & 32 & 17 & 4007 & 23,57 & 67,34 & 3,19 & CP \\
\hline 2 & Materi & 20 & 20 & 4 & 2247 & 13,21 & 66,08 & 2,71 & CP \\
\hline 3 & Sosial & 35 & 33 & 15 & 3992 & 23,45 & 67,02 & 3,58 & CP \\
\hline 4 & Emosi & 35 & 35 & 18 & 4330 & 25,47 & 72,77 & 2,94 & P \\
\hline 5 & Moral & 25 & 25 & 11 & 2972 & 17,48 & 69,92 & 2,52 & P \\
\hline 6 & Kognitif & 15 & 14 & 6 & 1772 & 10,42 & 69,49 & 1,37 & P \\
\hline & Keseluruhan & 165 & 139 & 89 & 19320 & 113,6 & 68,88 & 10,59 & P \\
\hline
\end{tabular}

Berdasarkan Tabel 2 diperoleh informasi bahwa, dari keseluruhan indikator konsep diri siswa secara rata-rata berada pada kategori positif (P) dengan persentase sebesar 68,88\% dari skor ideal. Dengan kata lain, konsep diri siswa dapat dikatakan baik. Konsep diri siswa terbentuk dan berkembang karena beberapa hal, di antaranya: fisik, materi, sosial, emosi, moral, dan kognitif. Konsep diri yang positif dapat digambarkan melalui perilaku siswa dalam berinteraksi di lingkungan dan bagaimana perilakunya tersebut berpengaruh terhadap orang lain.

\section{Hubungan Keharmonisan Keluarga dengan Konsep Diri}

Hasil analisis hubungan keharmonisan keluarga dengan konsep diri dapat dilihat pada Tabel 3.
Tabel 3. Hasil Analisis Keharmonisan Keluarga (X) dengan Konsep Diri (Y)

\begin{tabular}{c|c|c|c|c}
\hline Variabel & $\mathbf{N}$ & $\mathbf{R}$ & $\begin{array}{c}\boldsymbol{R} \\
\text { Square }\end{array}$ & Sig. \\
\hline $\mathrm{X}_{1} \mathrm{Y}$ & 170 & 0,436 & 0,190 & 0,000 \\
\hline
\end{tabular}

Berdasarkan Tabel 3 diperoleh angka koefisien korelasi variabel keharmonisan keluarga dengan konsep diri siswa sebesar 0,436 dan $\mathrm{R}$ Square (koefisien determinasi) sebesar 0,190. Berdasarkan kriteria, maka Ho ditolak dan $\mathrm{Ha}$ diterima. Selanjutnya nilai $\mathrm{R}$ Square $\left(\mathrm{R}^{2}\right)$ sebesar 0,190 yang berarti bahwa keharmonisan keluarga mampu memberikan sumbangan sebesar 19\% terbentuknya konsep diri siswa, sedangkan $81 \%$ dipengaruhi oleh faktor lain. 


\section{PEMBAHASAN}

\section{Keharmonisan Keluarga}

Hasil analisis data penelitian menunjukkan bahwa, secara ratarata keharmonisan keluarga siswa SMAN 1 Rao Pasaman berada pada kategori harmonis (H) dengan persentase sebesar 77,55\% dari ideal. Pencapaian ini sudah dapat dikatakan baik, walaupun pencapaian ini belum merupakan keadaan yang diharapkan. Hal ini bermakna bahwa pencapaian variabel keharmonisan keluarga siswa belum ideal, karena belum berada pada kategori sangat harmonis.

Hubungan dalam keluarga yang harmonis merupakan salah satu hal yang sangat penting untuk mencapai tujuan dalam keluarga. Dalam keluarga anak akan mendapatkan latihan-latihan dasar dalam mengembangkan sikap sosial, perilaku yang terkontrol, memperoleh pengertian tentang hak, kewajiban, tanggung jawab, serta belajar bekerja sama dan berbagi dengan orang lain. Lestari (2012) menyatakan proses yang berlangsung dalam keluarga lebih besar pengaruhnya terhadap akibatakibat pada diri anak, seperti rendahnya perilaku bermasalah dan kepuasan hidup. Proses dalam keluarga tersebut mencakup proses dalam relasi pasangan, relasi orangtua-anak, dan relasi kakak-adik yang lebih spesifik kepada kontrol dalam pengasuhan.

Kembali kepada hasil penelitian yang menunjukkan bahwa masih terdapat sebagian siswa yang mempersepsikan keadaan keluarganya berada pada kategori cukup harmonis. Hal ini hendaknya menjadi perhatian bagi Guru BK/Konselor untuk memberikan layanan yang mendukung di antaranya adalah layanan informasi. Layanan informasi dapat memantapkan wawasan, pengetahuan, keterampilan, nilai, dan sikap (WPKNS) siswa berkenaan dengan keharmonisan keluarga, sehingga siswa lebih memahami dan dapat menerapkan informasi yang disampaikan dalam keluarga sehingga keharmonisan dalam keluarga tetap terjaga. Selain layanan informasi, layanan bimbingan kelompok, dan layanan konseling kelompok dapat diberikan untuk melatih kepribadian, kemampuan berkomunikasi siswa, dan mampu untuk mengentaskan permasalahan yang dialami guna mendukung terciptanya kehidupan keluarga yang harmonis.

\section{Konsep Diri}

Hasil analisis menunjukkan bahwa secara keseluruhan konsep diri siswa SMAN 1 Rao Pasaman berada pada kategori positif (P), dengan persentase sebesar $68,88 \%$ dari ideal. Pencapaian ini belum merupakan keadaan yang diharapkan, hanya sebagian kecil siswa yang memiliki konsep diri sangat positif. Hal ini berarti bahwa pencapaian variabel konsep diri siswa belum ideal, karena belum berada pada kategori sangat positif. Kemudian masih terdapat konsep diri siswa yang berada pada kategori cukup positif.

Acocella (dalam Yunistiati, 2014) menjelaskan bahwa konsep diri yang positif lebih kepada penerimaan diri individu yang bersifat stabil dan bervariasi. Berdasarkan hasil peneitian pada aspek-aspek pada konsep diri siswa perlu menjadi perhatian karena akan berdampak pada berkembangnya konsep diri negatif siswa. Menurut 
Brooks \& Emmert (dalam Rakhmat, 2005) salah satu ciri orang yang memiliki konsep diri negatif yaitu cenderung menghindari dialog yang terbuka, dan bersikeras mempertahankan pendapatnya dengan berbagai justifikasi atau logika yang keliru. Hasil penelitian Yunistiati (2014) menunjukkan bahwa konsep diri yang negatif akan mengarah pada perilaku yang negatif, penghargaan diri yang tidak realistik, harga diri yang rendah, dan takut tidak berhasil.

Berdasarkan uraian di atas, hasil penelitian ini perlu dilakukan upaya untuk membantu siswa dalam menilai dirinya, salah satunya adalah melalui pelayanan BK di sekolah agar siswa mampu mengembangkan dan meningkatkan konsep diri yang positif.

\section{Hubungan Keharmonisan Keluarga dengan Konsep Diri}

Hasil penelitian menunjukkan bahwa terdapat hubungan yang positif dan signifikan antara keharmonisan keluarga dengan konsep diri. Temuan ini diperoleh berdasarkan hasil analisis data yang menunjukkan bahwa sumbangan keharmonisan keluarga terhadap konsep diri sebesar 19\%. Artinya variabel keharmonisan keluarga dapat digunakan sebagai prediktor untuk memprediksikan konsep diri. Keadaan keluarga yang harmonis dibutuhkan remaja untuk membentuk dan mengembangkan konsep diri yang positif. Keluarga merupakan bagian terpenting dari kehidupan seorang anak, karena di dalam keluarga anak pertama kali belajar tentang segala hal, baik berinteraksi maupun norma-norma yang berlaku dalam keluarga dan masyarakat. $\begin{array}{lr}\text { Hurlock } & (2004) \\ \text { mengemukakan } & \text { bahwa } \\ \text { ketidakmatangan dalam } & \text { hubungan } \\ \text { keluarga seperti yang ditunjukkan } \\ \text { adanya pertengkaran } & \text { dengan } \\ \text { anggota keluarga, terus menerus } \\ \text { mengkritik atau memberi komentar } \\ \text { yang merendahkan akan }\end{array}$ memberikam efek buruk psikologis terutama masa remaja, karena pada saat ini remaja sangat tidak percaya pada diri sendiri dan bergantung pada keluarga untuk memperoleh rasa aman. Oleh karena itu, hubungan baik dalam keluarga sangat dibutuhkan untuk membentuk pola kepribadian yang baik bagi remaja. Keharmonisan dalam keluarga membantu anak dalam pengembangan kepribadian yang positif.

Darahim (2015) menyatakan bahwa keluarga sebagai wahana untuk mengaktualisasikan konsep jati diri sebagai manusia yang seutuhnya dalam kehidupan pribadi, masyarakat, serta bangsa. Kondisi keluarga yang harmonis mampu menciptakan konsep diri yang positif pada individu karena individu mendapat kasih sayang, perhatian, dukungan, dan kehangatan dari keluarganya. Hasil penelitian Susanti (2008) menunjukkan bahwa terdapat hubungan keharmonisan keluarga dengan konsep diri sebesar $13,3 \%$. Individu yang memiliki konsep diri yang positif.

Mudjiran, Prayitno, Hasan, \& Ilyas (1999) menjelaskan lingkungan keluarga dengan situasi sosio-emosional dapat membentuk konsep diri internal yang sehat dan positif pada diri remaja yang dapat dilihat dari aktifitas dan disiplin yang diarahkan oleh kekuatan dari dalam diri (keyakinan diri, penilaian diri yang baik tentang kemampuan- 
kemampuannya), sehingga para remaja merasa bahagia dalam mengekspresikan diri sendiri.

\section{IMPLIKASI}

Berdasarkan temuan dan pembahasan hasil penelitian, maka dapat dikemukakan kesimpulan sebagai berikut:

1. Keharmoisan keluarga siswa SMAN 1 Rao Pasaman secara rata-rata berada pada kategori harmonis.

2. Konsep diri siswa SMAN 1 Rao Pasaman secara rata-rata berada pada kategori positif.

3. Terdapat hubungan yang positif dan signifikan antara keharmonisan keluarga dengan konsep diri. Apabila keharmonisan keluarga tinggi, maka konsep diri siswa juga positif, atau sebaliknya, apabila keharmonisan keluarga rendah, maka akan mengakibatkan konsep diri siswa juga rendah.

\section{REFERENSI}

Darahim, A. 2015. Membina Keharmonisan dan Ketahanan Keluarga. Jakarta: IPGH.

Familia. 2006. Konsep Diri Positif Menentukan Prestasi Anak. Yogyakarta: Kanisius.

Ghufron, M. N., \& Risnawati, R. 2010. Teori-teori Psikologi. Jakarta: Gramedia.

Hurlock, E. B. 1978. Perkembangan Anak: Jilid 2 (Edisi keenam). Alih Bahasa oleh Meitasari Tjandrasa. 2013. Jakarta: Erlangga.

Lestari, S. 2012. Psikologi Keluarga. Jakarta: Kencana.

Mudjiran. Prayitno, E. Hasan, M., \& Ilyas, A. 1999. Perkembangan Peserta Didik. Padang: UNP Press.

Papalia, D. E. \& Feldman, R.D. 2014. Experience

Human
Developement: $\quad$ Menyelami perkembangan manusia, (Edisi 12) Buku 2. Alih Bahasa: Fitriana Wuri Herarti. Jakarta: Salemba Humanika.

Rakhmat, J. 2005. Psikologi Komunikasi. Bandung: Remaja Rosdakarya.

Susanti, J. 2008. "Hubungan antara Persepsi terhadap Keharmonisan Keluarga dengan Konsep Diri pada Remaja”. Naskah Puplikasi. Fakultas Psikologi dan Ilmu Sosial Budaya Universitas Islam Indonesia,

(Online), (http://psychology.uii.ac .id/images/stories/jadwal_kuliah/ naskah-publikasi-04320159.pdf, diakses 11 Januari 2016).

Winkel, W. S. 2007. Bimbingan dan Konseling di Institusi Pendidikan. Yogyakarta: Media Abadi.

Yunistiati. 2014. Keharmonisan Keluarga, Konsep Diri, dan Interaksi Sosial Remaja. Jurnal Psikologi Indonesia, 3 (01): 7182. 